\title{
Vitamin D deficiency is associated with cortical bone loss and fractures in the elderly
}

\author{
F P Paranhos-Neto', L Vieira Neto', M Madeira', A B Moraes', L M C Mendonça², \\ I C B Lima3 , C L R Chagas4, D A Lira4, J F Spitz", J A M Guimarães4, M E L Duarte ${ }^{4}$ and \\ M L F Farias'
}

${ }^{1}$ Division of Endocrinology, ${ }^{2}$ Division of Reumathology, Clementino Fraga Filho University Hospital, UFRJ, Rio de Janeiro, Rio de Janeiro, Brasil, ${ }^{3}$ Program of Nuclear Engineering - COPPE - UFRJ, Rio de Janeiro, Rio de Janeiro, Brasil, and ${ }^{4}$ Research Division, National Institute of Orthopedics and Traumatology, Rio de Janeiro, Rio de Janeiro, Brazil
Correspondence should be addressed to F P Paranhos-Neto Email

francisco.paranhos@hotmail. com

\begin{abstract}
Introduction: The role of vitamin D on bone microarchitecture and fragility is not clear.

Objective: To investigate whether vitamin D deficiency $(25(\mathrm{OH}) \mathrm{D}<20 \mathrm{ng} / \mathrm{mL})$ increases cortical bone loss and the severity of fractures.

Design: Cross-sectional study of 287 elderly women with at least one prevalent low-impact fracture.

Methods: Biochemistry, X-rays to identify vertebral fractures (VFs) and to confirm non-vertebral fractures (NonVFs), and high-resolution peripheral quantitative computed tomography (HR-pQCT) to evaluate bone microstructure.

Results: Serum 25(OH)D levels were associated with body mass index (BMI: $r=-0.161, P=0.006), \mathrm{PTH}(r=-0.165$; $P=0.005), \mathrm{CTX}(r=-0.119 ; P=0.043)$ and VBMD at cortical bone (Dcomp: $r=0.132 ; P=0.033)$ and entire bone (D100: $r=0.162 P=0.009$ ) at the distal radius, but not at the tibia. Age and PTH levels were potential confounding variables, but in the multiple linear regressions only BMI $(95 \% \mathrm{Cl}: 0.11-4.16 ; P<0.01), 25(\mathrm{OH}) \mathrm{D}(95 \% \mathrm{Cl}:-0.007$ to $1.70 ; P=0.05)$ and CTX (95\% Cl: -149.04 to 21.80; $P<0.01)$ predicted Dcomp, while BMI $(95 \% \mathrm{Cl}: 1.13-4.18 ; P<0.01)$ and $25(\mathrm{OH}) \mathrm{D}$ (95\% Cl: $0.24-1.52 ; P<0.01)$ predicted D100. NonVFs predominated in patients with $25(\mathrm{OH}) \mathrm{D}<20 \mathrm{ng} / \mathrm{mL}(P=0.013)$. Logistic regression analysis showed a decrease in the likelihood of presenting grade 2-3 VFs/NonVFs for every increase in $25(\mathrm{OH}) \mathrm{D}(\mathrm{OR}=0.962,95 \% \mathrm{Cl}: 0.940-0.984 ; P=0.001)$, $\mathrm{BMI}(\mathrm{OR}=0.932,95 \% \mathrm{Cl}: 0.885-0.981 ; P=0.007)$ and $\mathrm{D} 100$ at radius (OR $=0.994,95 \% \mathrm{Cl}: 0.990-0.998 ; P=0.005)$.

Conclusion: In elderly patients with prevalent fractures, vitamin D deficiency was associated with cortical bone loss and severity of fractures.
\end{abstract}

\section{Introduction}

Vitamin D is an important regulator of skeletal health. Vitamin D content in diet is usually low and the main source of vitamin D in humans is the cutaneous conversion of 7-dehydroxycholesterol under ultraviolet light. In the elderly population, reduced sun exposure and atrophic skin impairs vitamin D synthesis (1). The consequences of vitamin D deficiency include a trend toward secondary hyperparathyroidism, increased bone turnover and bone loss $(2,3)$. Alterations in bone density and microarchitecture and a propensity to fall also contribute to the occurrence of fragility fractures in these patients $(1,4)$. Some authors identify the hip as the site more susceptible to fractures associated with vitamin D deficiency and hyperparathyroidism $(5,6$, $7,8)$. Nevertheless, the impact of alterations in bone metabolism, bone microstructure and the type of fracture associated with vitamin $\mathrm{D}$ deficiency remains an open question. 


\section{Subjects and methods}

\section{Study population}

This cross-sectional study included female patients from the Osteoporosis Prevention Study (OSTEOPREV) database that was held at the National Institute of Traumatology and Orthopedics and Federal University of Rio de Janeiro in Rio de Janeiro, Brazil. The study was performed with approval of the Institute Review Board (IRB no. 0005.0.305.000-09) and all participants provided written informed consent. The aim of the OSTEOPREV study was to evaluate patients at the age of 60 years and older who sustained a low-impact fracture at $\geq 50$ years old, including VFs detected on radiological examination. After media advertising, 3200 people made a first contact by phone for a preliminary screening. From this total 893 met the inclusion criteria and were invited to attend a medical interview. One hundred forty-one volunteers did not meet the inclusion criteria on further examination and were thus excluded from the study. A total of 752 participants were referred for radiographic examination, and those with at least one grade $1 \mathrm{VF}$ and/or one NonVF were submitted to laboratory tests. At the end of the screening process 340 patients (287 female) fulfilled the inclusion criteria (Fig. 1).

Patients with a fracture of the skull, facial bones, metacarpals, fingers, and toes, and fractures associated with high-energy trauma were not enrolled in the study. Exclusion criteria were alcoholism ( $>3$ standard drinks per day), malignancy, chronic inflammatory diseases, AIDS, untreated hyperthyroidism or hypothyroidism, primary hyperparathyroidism, hypoparathyroidism, elevated aminotrasferase levels and impaired renal function (estimated creatinine clearance $<30 \mathrm{~mL} / \mathrm{min} / 1.73 \mathrm{~m}^{2}$ as assessed by means of the CKD-EPI equation) (9). Current use of glucocorticoids, combined antiretroviral therapy for HIV-infection and anticonvulsants were also part of exclusion criteria. Anti-osteoporotic drugs (bisphosphonates, denosumab, strontium ranelate, teriparatide) should have been discontinued more than 1 year prior to study initiation. Patients with arterial hypertension and type 2 diabetes mellitus (T2DM) on adequate diet and in use of metformin as the only antidiabetic drug were included in the study.

Height and weight were measured to calculate body mass index (BMI: weight $/$ height $^{2}$ ). Patients were assessed retrospectively for a history of falls in the last year (one or more falls per month was considered frequent falls).

\section{X-rays}

Frontal and lateral plain radiographs of thoracic and lumbar spine were performed in all participants in order to identify and classify VFs based on Genant's semiquantitative method according to deformities of vertebral bodies as grade 1 (mild: $20-25 \%$ ), grade 2 (moderate: $25-40 \%$ ) or grade 3 (severe: $>40 \%$ ) (10). All radiographs were analyzed by two senior orthopedic surgeons (F P P and J A M G) and, in case of disagreement, the two authors reviewed the diagnosis to reach consensus. Previous NonVFs were also confirmed by new radiographs of the respective sites.

\section{HR-pQCT}

Volumetric bone density and bone microstructure were evaluated by high resolution peripheral quantitative computed tomography (HR-pQCT) using the X-TREME CT device (Scanco Medical AG, Bassedorf, Switzerland). The distal radius of the non-dominant arm and the ipsilateral distal tibia were used for analysis except in the case of a previous fracture in either region. From each site, 110 slices of $82 \mathrm{~mm}$ thickness (voxel dimension) were obtained and then digitized to generate a 3D representation of approximately $9 \mathrm{~mm}$ in the axial direction. The starting region for image acquisition was $9.5 \mathrm{~mm}$ proximal to a reference line positioned at the margin of the distal articular surface of the radius, perpendicular to the long axis of the diaphysis, and $22.5 \mathrm{~mm}$ proximal to a reference line positioned in the same way on the articular surface of the distal tibia. The parameters analyzed were total bone density (D100, $\mathrm{mgHA} / \mathrm{cm}^{3}$ ), cortical bone density (Dcomp, $\mathrm{mgHA} / \mathrm{cm}^{3}$ ), trabecular bone density (Dtrab, $\mathrm{mgHA} / \mathrm{cm}^{3}$ ), cortical thickness (Ct.Th, $\mathrm{mm}$ ), ratio of bone volume/tissue volume (BV/TV, 1), trabecular number (Tb.N, 1/mm), trabecular thickness (Tb.Th, mm), trabecular separation (Tb.Sp, $\mathrm{mm}$ ), and standard deviation of trabecular number, which reflects the heterogeneity of the trabecular network (Tb.1/N.SD, mm). All HR-pQCTderived bone values obtained at distal radius and distal tibia were considered for statistical analysis.

\section{Biochemistry}

Blood samples were drawn between 8:00 and 10:00 h after an overnight fast. Methods employed and reference values were as follows: calcium (RV: $8.5-10.1 \mathrm{mg} / \mathrm{dL}$ ), phosphorus (RV: $3.0-4.5 \mathrm{mg} / \mathrm{dL}$ ), albumin (RV: $3.5-5.5 \mathrm{~g} / \mathrm{dL}$ ) and creatinine (RV: $0.8-1.3 \mathrm{mg} / \mathrm{dL}$ ) were measured by routine methods. The glomerular filtration rate (GFR) was 


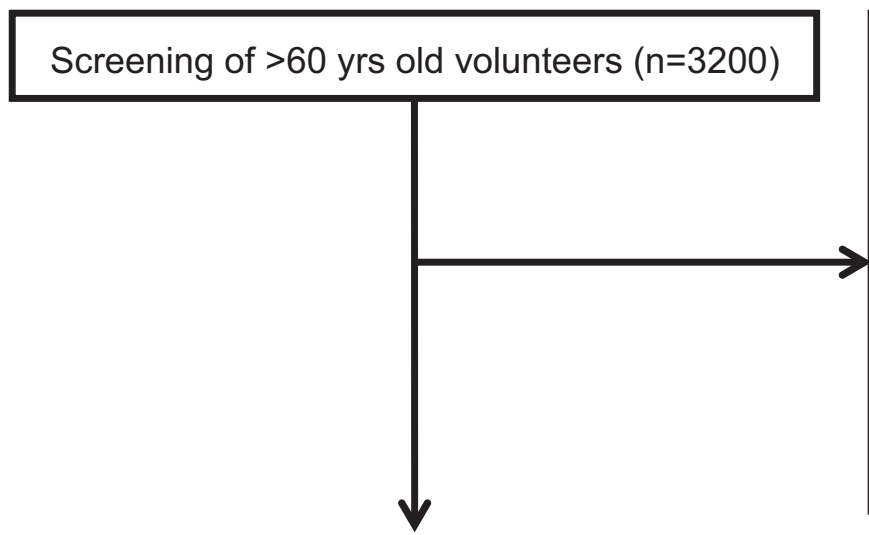

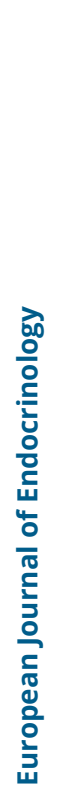

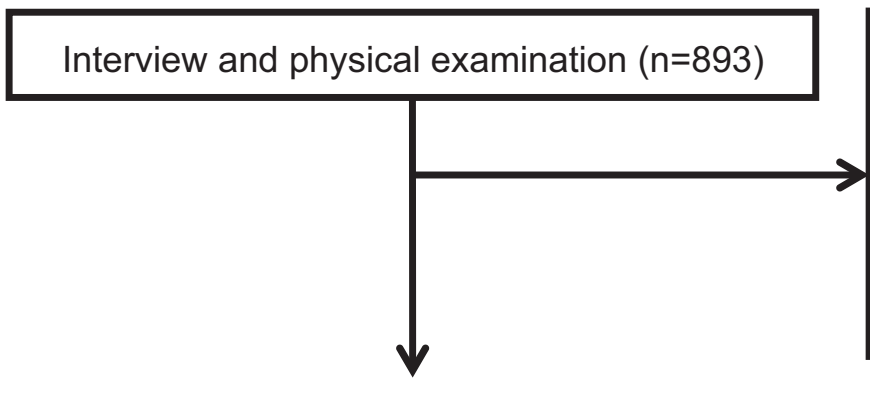

\section{Excluded $(n=2.307)$}

Age $<60$ years $(n=234)$

Loss of follow-up/refused to participate $(n=63)$

Active malignant neoplasm $(n=52)$

Chronic inflammatory disease $(n=437)$

HIVIAIDS $(n=27)$

Anticonvulsant agents $(n=48)$

Current glucocorticoid use $(n=109)$

Anti-resorptive agents $(n=1337)$

\section{Excluded $(n=141)$}

Loss of follow-up/refused to participate $(n=18)$

Chronic kidney disease $(n=6)$

Uncontrolled hypo or hyperthyroidism $(n=4)$

Anti-resorptive agents $(n=49)$

Other reasons $(n=64)$

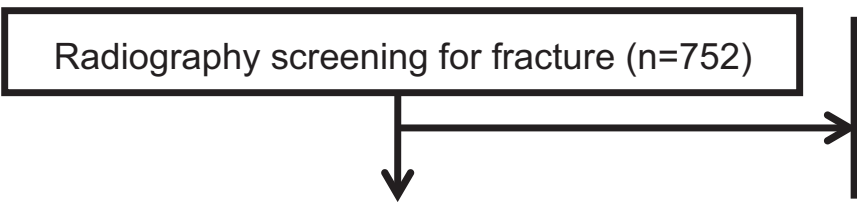

\section{Excluded $(n=370)$}

No fragility fractures $(n=370)$

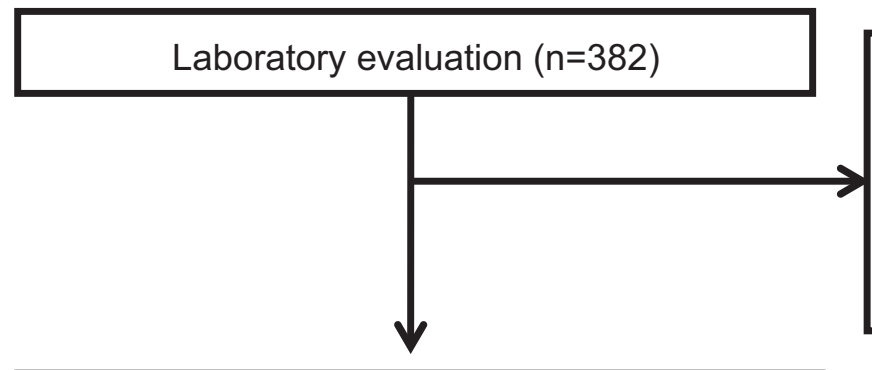

Patients that completed the study $(n=340)$

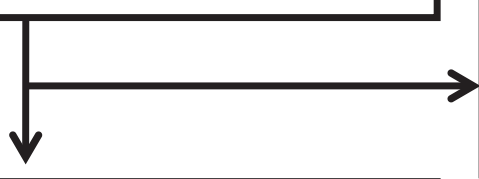

\section{Excluded $(n=53)$}

Male patients $(n=32)$

Women with unavailable $25(\mathrm{OHD})$ data $(n=21)$

\section{Women included to analysis $(n=287)$}

\section{Figure 1}

Flowchart of the selection strategy and inclusion/exclusion criteria in the study.

estimated by the Chronic Kidney Disease Epidemiology Collaboration equation (9). Serum 25(OH)D levels were assayed by electrochemiluminescence (Elecsys kit 2010, Roche; RV: $30-100 \mathrm{ng} / \mathrm{mL}$ ). According to the Endocrine Society guidelines, levels below $20 \mathrm{ng} / \mathrm{mL}(50 \mathrm{nmol} / \mathrm{L})$ indicated vitamin D deficiency, levels between 20 and $<30 \mathrm{ng} / \mathrm{mL}$ identified vitamin D insufficiency, whereas values at or higher than $30 \mathrm{ng} / \mathrm{mL}$ corresponded to vitamin D sufficiency (1). Intact parathyroid hormone (PTH) levels were assayed by chemiluminescence (IMMULITE $2000 \mathrm{kit}$; 
Siemens; RV: $11-65 \mathrm{pg} / \mathrm{mL}$ ). Bone resorption was evaluated by serum levels of carboxyterminal telopeptide of type I collagen (CTX) measured by electrochemiluminescence ( $\beta$-Cross Laps, Roche Diagnostics; RV for postmenopausal women $=0.104-1.008 \mathrm{ng} / \mathrm{mL}$ ).

\section{Statistical analysis}

In the descriptive analysis, categorical variables are expressed as percentages and their frequencies, whereas numerical variables are expressed as the mean \pm S.D. A normal distribution was assessed using the KolmogorovSmirnov test. Student's $t$-test or the Mann-Whitney test was used to compare numerical variables, as appropriate. ANOVA or the Kruskal-Wallis test was used to compare numerical variables among three groups $(25(\mathrm{OH}) \mathrm{D}$ $<20 \mathrm{ng} / \mathrm{mL}, 20$ to $<30 \mathrm{ng} / \mathrm{mL}$ and $\geq 30 \mathrm{ng} / \mathrm{mL}$ ), followed by Tukey's honestly significant difference post hoc test and a Bonferroni post hoc test, respectively. Correlations between numeric variables were analyzed using Pearson's correlation test. The $\chi^{2}$ test or Fisher's exact test was applied to compare categorical variables. The Nagelkerke determination coefficient was used for the binary logistic regression model. A $P$ value below 0.05 was considered statistically significant, and in the post hoc analysis, the $P$ value was adjusted according to the analysis. Analyses were performed using the statistical program SPSS, version 20.0 for Mac (SPSS Inc.).

\section{Results}

Study population comprised 287 elderly women who had normal values of serum calcium (corrected for albumin) and phosphorus. GFR was estimated to

Table 1 Anthropometric and biochemical characteristics of the whole population of elderly women with prevalent low-impact fractures. Values are expressed as mean \pm S.D.

\begin{tabular}{l} 
Parameters \\
\hline Age (years) \\
Body mass index $\left(\mathrm{kg} / \mathrm{m}^{2}\right)$ \\
Serum calcium $(\mathrm{mg} / \mathrm{dL})$ \\
Serum phosphorus $(\mathrm{mg} / \mathrm{dL})$ \\
Serum albumin $(\mathrm{g} / \mathrm{dL})$ \\
GFR $\left(\mathrm{ml} / \mathrm{min} / 1.73 \mathrm{~m}^{2}\right)$ \\
$25(\mathrm{OH})$ D $(\mathrm{ng} / \mathrm{mL})$ \\
Serum PTH $(\mathrm{pg} / \mathrm{mL})$ \\
Serum CTX $(\mathrm{ng} / \mathrm{mL})$ \\
\hline
\end{tabular}

\begin{tabular}{ccc}
\hline Mean \pm S.D. & & Reference values \\
\cline { 1 - 1 } $70.8 \pm 6.7$ & & \\
$29.4 \pm 5.6$ & & $20-27$ \\
$9.4 \pm 0.6$ & & $8.5-10.1$ \\
$3.6 \pm 0.5$ & & $3.0-4.5$ \\
$4.1 \pm 0.5$ & & $3.5-5.5$ \\
$76.6 \pm 15.0$ & & $\geq 60$ \\
$24.7 \pm 12.9$ & & $30-100$ \\
$46.5 \pm 20.3$ & & $11-65$ \\
$0.335 \pm 0.188$ & & $0.104-1.008$ \\
& &
\end{tabular}

Reference values considered the elderly/osteoporotic population. CTX, C-terminal telopeptide of type I collagen; GFR, glomerular filtration rate was estimated by the formula CKD-EPI; PTH, parathyroid hormone. be $\geq 60 \mathrm{ml} / \mathrm{min} / 1.73 \mathrm{~m}^{2}$ in 250 patients and between 32 and $60 \mathrm{~mL} / \mathrm{min} / 1.73 \mathrm{~m}^{2}$ in 37 patients. Serum PTH was $>65 \mathrm{pg} / \mathrm{mL}$ in 44 patients $(15.34 \%)$, and CTX was within the $0.104-1.008 \mathrm{ng} / \mathrm{mL}$ range in all patients. The characteristics of the sample are shown in Table 1.

Most patients diagnosed with a mild morphometric vertebral fracture were not aware of having osteoporosis, and thus, did not refer previous use of anti-osteoporosis drugs. Those who ever received alendronate or risedronate had it discontinued for more than 2 years before entering the study. None of the participants reported previous or current use of ibandronate, strontium ranelate, zoledronic acid, denosumab or teriparatide, or were receiving calcium and vitamin D supplements when they were allocated in the study.

Serum 25(OH)D was $<20 \mathrm{ng} / \mathrm{mL}$ in 114 patients (D-deficient), between 20 and $<30 \mathrm{ng} / \mathrm{mL}$ in 82 patients (D-insufficient), and $\geq 30 \mathrm{ng} / \mathrm{mL}$ in 91 patients (D-sufficient). Comparisons among these three subgroups showed that D-sufficient patients, as compared to those D-deficient, had significantly higher calcium $(9.57 \pm 0.56$ vs $9.23 \pm 0.68 \mathrm{mg} / \mathrm{dL} \quad P<0.001)$, higher phosphorus $(3.70 \pm 0.53$ vs $3.53 \pm 0.48 \mathrm{mg} / \mathrm{dL} ; P=0.016)$ and a trend toward higher D100 $(285.00 \pm 81.07$ vs $\left.262.45 \pm 67.70 \mathrm{mgHA} / \mathrm{cm}^{3}, \quad P=0.07\right)$ and higher Ct.Th $(0.68 \pm 0.22$ vs $0.62 \pm 0.20 \mathrm{~mm}, P=0.08)$ at distal radius. D-sufficient patients, compared to those D-insufficient, also tended to have lower PTH values $(42.01 \pm 15.04$ vs $48.66 \pm 24.40 \mathrm{pg} / \mathrm{mL}, P=0.02$ ). Complete data of all comparisons are shown in Supplementary Table 1 (see section on supplementary data given at the end of this article).

Twenty-three patients with 25(OH)D below 20ng/ $\mathrm{mL}$ had PTH levels above normal limits. However, no significant differences in bone density or microstructure were observed when they were compared with D-deficient patients without secondary hyperparathyroidism.

Linear correlations are shown in Table 2. BMI had a negative influence on $25(\mathrm{OH}) \mathrm{D}$ levels, but a positive association with vBMD. 25(OH)D was inversely correlated with PTH and CTX. Finally, low 25(OH)D and high CTX were associated with decreased vBMD at the cortical and entire bone at the distal radius. No significant correlation was found with bone parameters measured at the distal tibia.

When the relationships between age, BMI, PTH, 25(OH)D, CTX and all HR-pQCT derived bone parameters were examined in a multiple linear regression, CTX (95\% CI -149.04-21.80; $P<0.01)$, BMI (95\% CI $0.11-4.16$; $P<0.01)$, and 25(OH)D (95\% CI -0.007 to $1.70 ; P=0.05)$ 
Table 2 Significant associations between anthropometry, biochemistry and HR-pQCT parameters at the distal radius using Pearson correlation test.

\begin{tabular}{|c|c|c|c|c|c|}
\hline & 25(OH)D & PTH & D100-R & Dcomp-R & Dtrab-R \\
\hline 25(OH)D & 1 & & & & \\
\hline$r$ & & -0.165 & 0.162 & 0.132 & \\
\hline$P$ & & 0.005 & 0.009 & 0.033 & \\
\hline \multicolumn{6}{|l|}{ CTX } \\
\hline$r$ & -0.119 & 0.220 & -0.148 & -0.198 & \\
\hline$P$ & 0.043 & $<0.001$ & 0.016 & 0.001 & \\
\hline \multicolumn{6}{|l|}{ BMI } \\
\hline$r$ & -0.161 & 0.280 & 0.186 & & 0.129 \\
\hline$P$ & 0.006 & $<0.001$ & 0.002 & & 0.037 \\
\hline
\end{tabular}

BMI, body mass index; CTX, C-telopeptide of type I collagen; D100, Dcomp and Dtrab, volumetric bone mineral density at entire bone, cortical and trabecular compartments, respectively, measured at the distal radius.

significantly predicted cortical density, and 25(OH)D (95\% CI 0.24-1.52; $P<0.01)$ and BMI (95\% CI 1.13-4.18; $P<0.01)$ significantly predicted total bone density at the distal radius.

Forty-three patients had previous NonVFs (wrist, ribs, shoulder, pelvis and femoral neck); in 22 of these patients, VFs were also detected by X-ray examination. The remaining 234 patients had only VFs. In the whole population, 556 fractures were confirmed (477 VFs and 79 NonVFs, 21 of which in the femoral neck).

To investigate the influence of vitamin $\mathrm{D}$ deficiency on fractures, patients with $25(\mathrm{OH}) \mathrm{D}$ blood levels $<20 \mathrm{ng} /$ $\mathrm{mL}$ were compared with patients with levels $\geq 20 \mathrm{ng} / \mathrm{mL}$. The prevalence of type 2 diabetes mellitus in patients considered D-deficient (15.8\%) and all others (15.0\%) was not significantly different $(P=0.895)$. Similarly, the prevalence of arterial hypertension in D-deficient patients (52.6\%) and all others (53.1\%) was not significantly different $(P=0.913)$. NonVFs were more likely to occur in patients with $25(\mathrm{OH}) \mathrm{D}<20 \mathrm{ng} / \mathrm{mL}$, whereas patients with vitamin D levels $>20 \mathrm{ng} / \mathrm{mL}$ had less severe fractures, classified as grade 1 VFs (Table 3). Using $30 \mathrm{ng} / \mathrm{mL}$ as the cutoff, the differences in fractures lost significance.

A binary logistic regression model was conducted to assess whether $\mathrm{BMI}, 25(\mathrm{OH}) \mathrm{D}$, and $\mathrm{D} 100$ at the radius significantly predicted if the patient presented only a grade $1 \mathrm{VF}$ or more severe fractures (grade 2-3 VF and/or NonVF). Considering the variables (BMI, 25(OH)D, and D100 at radius) that were statistically significant in the bivariate analysis, the model was statistically significant for predicting fracture grade. In fact, there was a decrease in the likelihood of presenting with a grade 2-3 VF/NonVF for every increase in BMI $(\mathrm{OR}=0.932,95 \% \mathrm{CI}$ : 0.885-0.981; $P=0.007), 25(\mathrm{OH}) \mathrm{D}$ level $(\mathrm{OR}=0.962,95 \% \mathrm{CI}$ : 0.940-0.984;
$P=0.001)$, and $\mathrm{D} 100$ at the radius $(\mathrm{OR}=0.994,95 \% \mathrm{CI}$ : 0.990-0.998; $P=0.005)$. The Omnibus Tests of Model Coefficients indicates that when all three predictors are considered together, the equation is significant $\left(\chi^{2}=32.27\right.$; $\mathrm{df}=3 ; n=263 ; R^{2}$ Nagelkerke $\left.=0.16 ; P<0.001\right)$.

According to the structured questionnaire, $39.6 \%$ of the patients reported frequent accident falls in routine everyday activities. The influence of 25(OH)D levels on frequent falls was also tested, but there was no significant influence considering a cutoff value of $20 \mathrm{ng} / \mathrm{mL}(P=0.79)$.

\section{Discussion}

This study in elderly women with osteoporosis and at least one low trauma fracture suggested that vitamin D deficiency has a negative impact on cortical bone density and is associated with the occurrence of severe vertebral and NonVFs.

Vitamin D plays an important role in skeletal homeostasis throughout life. The definition of vitamin D adequacy is still a matter of debate and varies according to the patient's age and overall health. Serum levels of 25(OH)D near $20 \mathrm{ng} / \mathrm{mL}(50 \mathrm{nmol} / \mathrm{L})$ may be adequate for a large population (11), but many authors consider $30 \mathrm{ng} / \mathrm{mL}(75 \mathrm{nmol} / \mathrm{L})$ as the minimum concentration to guarantee bone health in elderly people, especially in those with osteoporosis and fragility fractures $(1,12,13)$.

In the elderly population with prevalent nontraumatic fractures included in this study, 25(OH)D levels were below $30 \mathrm{ng} / \mathrm{mL}$ in 196 patients (68.3\%). Even considering

Table 3 Comparisons of vertebral and non-vertebral fractures between subgroups according to 25(OH)D levels. Values expressed as absolute number of fractures (number of fractures for 100 patients). Other non-vertebral fractures included wrist (Colles), ribs, shoulder and pelvis).

\begin{tabular}{|c|c|c|c|}
\hline & \multicolumn{2}{|c|}{ 25(OH)D } & \multirow[b]{2}{*}{$\boldsymbol{P}$} \\
\hline & $\begin{array}{c}<20 \mathrm{ng} / \mathrm{mL} \\
(n=114)\end{array}$ & $\begin{array}{c}\geq 20 \mathrm{ng} / \mathrm{mL} \\
(n=173)\end{array}$ & \\
\hline Vertebral grade 1 & $100(88)$ & 205 (119) & 0.031 \\
\hline Vertebral grade 2 & $41(36)$ & $58(34)$ & 0.811 \\
\hline Vertebral grade 3 & $28(25)$ & $45(26)$ & 0.889 \\
\hline $\begin{array}{l}\text { Vertebral fractures } \\
\text { (all grades) }\end{array}$ & $169(148)$ & $308(178)$ & 0.097 \\
\hline Femoral neck & $13(11)$ & $8(5)$ & 0.134 \\
\hline $\begin{array}{l}\text { Other non- } \\
\text { vertebral }\end{array}$ & $31(27)$ & $27(16)$ & 0.093 \\
\hline $\begin{array}{l}\text { Non-vertebral } \\
\text { fractures }\end{array}$ & $44(39)$ & $35(20)$ & 0.013 \\
\hline All fractures & $213(187)$ & $343(198)$ & 0.575 \\
\hline
\end{tabular}


$20 \mathrm{ng} / \mathrm{L}$ as a cutoff, 114 patients (39.7\%) were found to be vitamin D-deficient. Aging per se contributes to decreased vitamin synthesis in the skin, the main source of vitamin $\mathrm{D}$ in humans (2). The sequestration of vitamin $\mathrm{D}$ by adipose tissue is a possibility to be considered (14) as BMI was inversely correlated with $25(\mathrm{OH}) \mathrm{D}$ levels. The inverse correlation between PTH and $25(\mathrm{OH}) \mathrm{D}$ levels is possibly associated to low levels of dietary calcium previously described in the Brazilian population $(15,16)$, though not evaluated in this study.

Regardless of the mechanism, it is quite likely that the hormonal imbalance contributed significantly to the increase of the turnover and of the bone loss. This is consistent with findings of elderly populations $(2,3,4,7$, 17) including a population survey in Brazil $(18,19)$.

Reports on the association of vitamin $\mathrm{D}$ deficiency and hip fracture $(5,6)$ suggest a preferential bone loss at the cortical compartment. Approximately $85 \%$ of the human skeleton is composed of compact (cortical) bone, demanding a great amount of calcium to mineralize newly formed bone matrix, which is provided by vitamin D-dependent intestinal calcium absorption. PTH hypersecretion has also been related to cortical bone loss in a study based on bone biopsies from patients with primary hyperparathyroidism (20). Although compact bone has less surface exposure for remodeling than trabecular bone, studies of bone samples taken from cadavers showed a progressive increase in intracortical bone resorption with aging, leading to increased cortical porosity (21). These changes contribute significantly to overall bone fragility, including at the vertebrae, where trabecular bone predominates (22).

The possibility of evaluating bone microstructure by a noninvasive method such as HR-pQCT greatly increased our knowledge of bone changes during the normal aging process $(23,24)$. Despite a modest correlation with microstructure parameters measured by histomorphometry (25), HR-pQCT is considered a reliable method to evaluate volumetric bone density and microarchitecture at the trabecular and cortical compartments. The measurement of cortical porosity and estimation of bone strength by Finite Element Analysis improve the ability to identify people at risk for fractures $(26,27,28,29,30,31)$.

Studies using peripheral computed tomography (pQCT and HR-pQCT) confirmed cortical derangement in primary hyperparathyroidism, but also showed that trabecular bone is not spared in this disease $(32,33)$. Few publications address the deleterious effect of vitamin D deficiency on bone microstructure, and the participation of secondary hyperparathyroidism cannot be ruled out (34, 35). In this study, cortical bone loss was associated with bone turnover and vitamin D levels, but not with PTH. Furthermore, no difference was found between patients with $25(\mathrm{OH}) \mathrm{D}$ below $20 \mathrm{ng} / \mathrm{mL}$ with $(n=23)$ or without $(n=91) \quad$ associated secondary hyperparathyroidism regarding bone density and microstructure. These findings are in agreement with the results of univariate and multivariate analyses. Also, a direct beneficial effect of vitamin D supplementation on bone microstructure and strength, rather than an effect mediated through lowering of PTH levels, was recently reported (36). Obesity may be beneficial for weight-bearing bones, although the positive effects on bone microstructure seem mostly related to lean mass, rather than to fat mass (37). In our study, BMI and $25(\mathrm{OH}) \mathrm{D}$ were independent predictors of cortical and entire bone vBMD, and the analysis of subgroups suggest that vitamin D levels $\geq 30 \mathrm{ng} / \mathrm{mL}$ may be of greater benefit for calcium-phosphorus homeostasis and bone microstructure.

All patients included in this study were selected based on at least one morphometric vertebral fracture; thus, we cannot associate hormone and bone derangements with the occurrence of fractures. For this reason, we chose to investigate the eventual contribution to the type of fragility fracture. The finding of a higher proportion of NonVFs in our patients with very low 25(OH)D levels seems consistent with more severe cortical bone loss, supported by the association of vitamin $\mathrm{D}$ and cortical bone density. Otherwise, less severe fractures, such as grade $1 \mathrm{VFs}$, were more common in those patients with higher vitamin D levels, who tended to have better bone density (D100) and cortical microstructure (Ct. Th). Cortical porosity has been identified as the main contributor to skeletal fragility at appendicular sites (38) and to the severity of VFs (39) in postmenopausal women. Cortical porosity was not measured in the current study, but our findings are consistent with studies describing this association $(31,40,41,42)$.

The increased bone fragility described in patients with type 2 diabetes mellitus (T2DM) is multifactorial and displays a preference for cortical bone $(43,44)$. Approximately $15 \%$ of the whole population presented T2DM, which might have had a negative impact on bone. However, T2DM was equally distributed in the subgroups of patients with $25(\mathrm{OH}) \mathrm{D}<20$ and $\geq 20 \mathrm{ng} /$ $\mathrm{mL}$ and thus could not explain the differences in bone microstructure and the increased frequency of NonVFs. 
Arterial hypertension is also considered a risk factor for fractures, although treatment with anti-hypertensive drugs seems to counterbalance the deleterious effects on bone (45). Approximately half of the patients was treated for arterial hypertension but equally distributed in the vitamin D subgroups, reducing possible interference with our findings.

Vitamin D deficiency can also contribute to sarcopenia and falls, increasing the risk for fractures (46). In our study, muscle mass and function were not investigated, and we did not observe an association between vitamin D levels and falls.

The limitations of our study include the measurement of serum $25(\mathrm{OH}) \mathrm{D}$ by electrochemiluminescence, rather than using the gold standard method that is isotope dilution liquid chromatography-mass spectrometry, the cross-sectional design which limits defining causality, and the lack of comparison with age-matched patients without fractures to better investigate the impact of vitamin $\mathrm{D}$ deficiency on bone microstructure and fractures. A therapeutic intervention with vitamin D supplementation targeting levels at or higher than $30 \mathrm{ng} / \mathrm{mL}$ could help identify improvements in bone microstructure and incident fractures in this elderly population with prevalent fractures.

The main conclusion of this cross-sectional study is that vitamin D deficiency and consequent disruptions to calcium-PTH homeostasis, bone turnover, and bone microstructure, especially in the cortical compartment, are associated with the occurrence of severe VFs and NonVFs. These results support the biochemical evaluation of serum levels of vitamin D and supplementation in elderly patients at high risk for fractures. This is in accordance with recent guideline proposals from the European Calcified Tissue Society (47).

\section{Supplementary data}

This is linked to the online version of the paper at https://doi.org/10.1530/ EJE-19-0197.

\section{Declaration of interest}

The authors declare that there is no conflict of interest that could be perceived as prejudicing the impartiality of this study.

\section{Funding}

This work was supported by Funding Authority for Studies and Projects (FINEP), Ministry of Science and Technology of Brazil (grant number 01.08.0647-00, 2012); and Brazilian National Council for Scientific and Technological Development (CNPq), Ministry of Science and Technology of Brazil (grant number 141704/2014-4).

\section{References}

1 Holick MF. Vitamin D deficiency. New England Journal of Medicine 2007357 266-281. (https://doi.org/10.1056/NEJMra070553)

2 Lips P. Vitamin D deficiency and secondary hyperparathyroidism in the elderly: consequences for bone loss and fractures and therapeutic implications. Endocrine Reviews 200122 477-501. (https://doi. org/10.1210/edrv.22.4.0437)

3 Sahota O, Mundey MK, San P, Godber IM, Lawson N \& Hosking DJ. The relationship between vitamin D and parathyroid hormone: calcium homeostasis, bone turnover, and bone mineral density in postmenopausal women with established osteoporosis. Bone 200435 312-319. (https://doi.org/10.1016/j. bone.2004.02.003)

4 Passeri G, Pini G, Troiano L, Vescovini R, Sansoni P, Passeri M, Gueresi P, Delsignore R, Pedrazzoni M \& Franceschi C. Low vitamin D status, high bone turnover, and bone fractures in centenarians. Journal of Clinical Endocrinology and Metabolism 200388 5109-5115. (https://doi.org/10.1210/jc.2003-030515)

5 Sakuma M, Endo N, Oinuma T, Hayami T, Endo E, Yazawa T, Watanabe K \& Watanabe S. Vitamin D and intact PTH status in patients with hip fracture. Osteoporosis International $2006 \mathbf{1 7}$ 1608-1614. (https://doi.org/10.1007/s00198-006-0167-1)

6 Ensrud KE, Taylor BC, Paudel ML, Cauley JA, Cawthon PM, Cummings SR, Fink HA, Barrett-Connor E, Zmuda JM, Shikany JM et al. Serum 25-hydroxyvitamin D levels and rate of hip bone loss in older men. Journal of Clinical Endocrinology and Metabolism 200994 2773-2780. (https://doi.org/10.1210/jc.2008-2786)

7 Sai AJ, Walters RW, Fang X \& Gallagher JC. Relationship between vitamin D, parathyroid hormone, and bone health. Journal of Clinical Endocrinology and Metabolism 201196 E436-E446. (https://doi. org/10.1210/jc.2010-1886)

8 Rejnmark L, Vestergaard P, Brot C \& Mosekilde L. Increased fracture risk in normocalcemic postmenopausal women with high parathyroid hormone levels: a 16-year follow-up study. Calcified Tissue International 201188 238-245. (https://doi.org/10.1007/ s00223-010-9454-0)

9 Levey AS, Stevens LA, Schmid CH, Zhang YL, Castro AF 3rd, Feldman HI, Kusek JW, Eggers P, Van Lente F, Greene T et al. A new equation to estimate glomerular filtration rate. Annals of Internal Medicine 2009150 604-612. (https://doi.org/10.7326/0003-4819150-9-200905050-00006)

10 Genant HK, Wu CY, van Kuijk C \& Nevitt MC. Vertebral fracture assessment using a semiquantitative technique. Journal of Bone and Mineral Research 19938 1137-1148. (https://doi.org/10.1002/ jbmr.5650080915)

11 Ross AC, Manson JE, Abrams SA, Aloia JF, Brannon PM, Clinton SK, Durazo-Arvizu RA, Gallagher JC, Gallo RL, Jones G et al. The 2011 report on dietary reference intakes for calcium and vitamin D from the Institute of Medicine: what clinicians need to know. Journal of Clinical Endocrinology and Metabolism 201196 53-58. (https://doi. org/10.1210/jc.2010-2704)

12 Schneider DL. Vitamin D and skeletal health. Current Opinion in Endocrinology and Diabetes 200613 483-490. (https://doi. org/10.1097/MED.0b013e328010ab20)

13 Holick MF, Binkley NC, Bischoff-Ferrari HA, Gordon CM, Hanley DA, Heaney RP, Hassan Murad MH, Weaver CM \& Endocrine Society. Evaluation, treatment, and prevention of vitamin D deficiency: an Endocrine Society Clinical Practice Guideline. Journal of Clinical Endocrinology and Metabolism 201196 1911-1930. (https://doi. org/10.1210/jc.2011-0385)

14 Wortsman J, Matsuoka LY, Chen TC, Lu Z \& Holick MF. Decreased bioavailability of vitamin D in obesity. American Journal of Clinical Nutrition 200072 690-693. (https://doi.org/10.1093/ajcn/72.3.690)

15 Pinheiro MM, Schuch NJ, Genaro PS, Ciconelli RM, Ferraz MB \& Martini LA. Nutrient intakes related to osteoporotic fractures in men 
and women - the Brazilian Osteoporosis Study (BRAZOS). Nutrition Journal 20098 6. (https://doi.org/10.1186/1475-2891-8-6)

16 Araujo MC, Junior EV, Junger WL \& Sichieri R. Independent associations of income and education with nutrient intakes in Brazilian adults: 2008-2009 National Dietary Survey. Public Health Nutrition 201417 2740-2752. (https://doi.org/10.1017/ S1368980013003005)

17 Garnero P, Sornay-Rendu E, Chapuy MC \& Delmas PD. Increased bone turnover in late postmenopausal women is a major determinant of osteoporosis. Journal of Bone and Mineral Research 199611 337-349. (https://doi.org/10.1002/jbmr.5650110307)

18 Bandeira F, Griz L, Freese E, Lima DC, Thé AC, Diniz ET, Marques TF \& Lucena CS. Vitamin D deficiency and its relationship with bone mineral density among postmenopausal women living in the tropics. Arquivos Brasileiros de Endocrinologia e Metabologia 201054 227-232. (https://doi.org/10.1590/S0004-27302010000200020)

19 Moreira ML, Vieira Neto LV, Madeira M, Lopes RF \& Farias MLF. Vitamin D deficiency and its influence on bone metabolism and density in a Brazilian population of healthy men. Journal of Clinical Densitometry 201821 91-97. (https://doi.org/10.1016/j. jocd.2017.01.008)

20 Parisien M, Silverberg SJ, Shane E, La Cruz L, Lindsay R, Bilezikian JP $\&$ Dempster DW. The histomorphometry of bone in primary hyperparathyroidism: preservation of cancellous bone structure. Journal of Clinical Endocrinology and Metabolism 199070 930-938. doi:10.1210/jcem-70-4-930.

21 Zebaze RMD, Ghasem-Zadeh A, Bohte A, Iuliano-Burns S, Mirams M, Price RI, Mackie EJ \& Seeman E. Intracortical remodeling and porosity in the distal radius and post-mortem femurs of women: a cross-sectional study. Lancet 2010375 1729-1736. (https://doi. org/10.1016/S0140-6736(10)60320-0)

22 Ritzel H, Amling M, Pösl M, Hahn M \& Delling G. The thickness of human vertebral cortical bone and its changes in aging and osteoporosis: A histomorphometric analysis of the complete spinal column from thirty-seven autopsy specimens. Journal of Bone and Mineral Research 199712 89-95. (https://doi.org/10.1359/ jbmr.1997.12.1.89)

23 Boutroy S, Bouxsein ML, Munoz F \& Delmas PD. In vivo assessment of trabecular bone microarchitecture by high-resolution peripheral quantitative computed tomography. Journal of Clinical Endocrinology and Metabolism 200590 6508-6515. (https://doi.org/10.1210/ jc.2005-1258)

24 Alvarenga JC, Fuller H, Pasoto SG \& Pereira RME. Age-related reference curves of volumetric bone density, structure, and biomechanical parameters adjusted for weight and height in a population of healthy women: an HR-pQCT study. Osteoporosis International 201728 1335-1346. (https://doi.org/10.1007/s00198016-3876-0)

25 Cohen A, Dempster DW, Müller R, Guo XE, Nickolas TL, Liu XS, Zhang XH, Wirth AJ, van Lenthe GH, Kohler T et al. Assessment of trabecular and cortical architecture and mechanical competence of bone by high-resolution peripheral computed tomography: comparison with transiliac bone biopsy. Osteoporosis International 201021 263-273. (https://doi.org/10.1007/s00198-009-0945-7)

26 Sornay-Rendu E, Boutroy S, Munoz F \& Bouxsein ML. Cortical and trabecular architecture are altered in postmenopausal women with fractures. Osteoporosis International 200920 1291-1297. (https://doi. org/10.1007/s00198-009-1008-9)

27 Boutroy S, Khosla S, Sornay-Rendu E, Zanchetta MB, McMahon DJ, Zhang CA, Chapurlat RD, Zanchetta J, Stein EM, Bogado C et al. Microarchitecture and peripheral BMD are impaired in postmenopausal white women with fracture independently of total hip T-score: an International Multicenter Study. Journal of Bone and Mineral Research 201631 1158-1166. (https://doi.org/10.1002/jbmr.2796)

28 Sornay-Rendu E, Boutroy S, Duboeuf F \& Chapurlat RD. Bone microarchitecture assessed by HR-pQCT as predictor of fracture risk in postmenopausal women: the OFELY Study. Journal of Bone and Mineral Research 201732 1243-1251. (https://doi.org/10.1002/ jbmr.3105)

29 Ahmed LA, Shigdel R, Joakimsen RM, Eldevik OP, Eriksen EF, Ghasem-Zadeh A, Bala Y, Zebaze R, Seeman E \& Bjørnerem Å. Measurement of cortical porosity of the proximal femur improves identification of women with nonvertebral fragility fractures. Osteoporosis International 201526 2137-2146. (https://doi. org/10.1007/s00198-015-3118-x)

30 Vilayphiou N, Boutroy S, Sornay-Rendu E, Van Rietbergen B \& Chapurlat R. Age-related changes in bone strength from HR-pQCT derived microarchitectural parameters with an emphasis on the role of cortical porosity. Bone 201683 233-240. (https://doi. org/10.1016/j.bone.2015.10.012)

31 Sundh D, Nilsson AG, Nilsson M, Johansson L, Mellström D \& Lorentzon M. Increased cortical porosity in women with hip fracture. Journal of Internal Medicine 2017281 496-506. (https://doi. org/10.1111/joim.12587)

32 Charopoulos I, Tournis S, Trovas G, Raptou P, Kaldrymides P, Skarandavos G, Katsalira K \& Lyritis GP. Effect of primary hyperparathyroidism on volumetric bone mineral density and bone geometry assessed by peripheral quantitative computed tomography in postmenopausal women. Journal of Clinical Endocrinology and Metabolism 200691 1748-1753. (https://doi. org/10.1210/jc.2005-2102)

33 Stein EM, Silva BC, Boutroy S, Zhou B, Wang J, Udesky J, Zhang C, McMahon DJ, Romano M, Dworakowski E et al. Primary hyperparathyroidism is associated with abnormal cortical and trabecular microstructure and reduced bone stiffness in postmenopausal women. Journal of Bone and Mineral Research 2013 28 1029-1040. (https://doi.org/10.1002/jbmr.1841)

34 Boyd SK, Burt LA, Sevick LK \& Hanley DA. The relationship between serum $25(\mathrm{OH}) \mathrm{D}$ and bone density and microarchitecture as measured by HR-pQCT. Osteoporosis International 201526 2375-2380. (https:// doi.org/10.1007/s00198-015-3110-5)

35 Rødbro LL, Bislev LS, Sikjær T \& Rejnmark L. Bone metabolism, density, and geometry in postmenopausal women with vitamin D insufficiency: a cross-sectional comparison of the effects of elevated parathyroid levels. Osteoporosis International 201829 2211-2218. (https://doi.org/10.1007/s00198-018-4602-x)

36 Bislev LS, Rødbro LL, Rolighed L, Sikjaer T \& Rejnmark L. Bone microstructure in response to vitamin D3 supplementation: a randomized placebo-controlled trial. Calcified Tissue International 2019104 160-170. (https://doi.org/10.1007/s00223-018-0481-6)

37 Madeira E, Mafort TT, Madeira M, Guedes EP, Moreira RO, de Mendonça LM, Lima IC, de Pinho PR, Lopes AJ \& Farias ML. Lean mass as a predictor of bone density and microarchitecture in adult obese individuals with metabolic syndrome. Bone 201459 89-92. (https://doi.org/10.1016/j.bone.2013.11.004)

38 Bjørnerem Å, Wang X, Bui M, Ghasem-Zadeh A, Hopper JL, Zebaze R $\&$ Seeman E. Menopause-related appendicular bone loss is mainly cortical and results in increased cortical porosity. Journal of Bone and Mineral Research 201833 598-605. (https://doi.org/10.1002/ jbmr.3333)

39 Sornay-Rendu E, Cabrera-Bravo JL, Boutroy S, Munoz F \& Delmas PD. Severity of vertebral fractures is associated with alterations of cortical architecture in postmenopausal women. Journal of Bone and Mineral Research 200924 737-743. (https://doi.org/10.1359/jbmr.081223)

40 Sakuma M, Endo N, Hagino H, Harada A, Matsui Y, Nakano T \& Nakamura K. Serum 25-hydroxyvitamin D status in hip and spinefracture patients in Japan. Journal of Orthopaedic Science 201116 418-423. (https://doi.org/10.1007/s00776-011-0089-4)

41 Lv QB, Gao X, Liu X, Shao Z-X, Xu Q-H, Tang L, Chi Y-L \& Wu A-M. The serum 25-hydroxyvitamin $D$ levels and hip fracture risk: a meta-analysis of prospective cohort studies. Oncotarget 20178 39849-39858. (https://doi.org/10.18632/oncotarget.16337) 
42 Sundh D, Mellström D, Ljunggren Ö, Karlsson MK, Ohlsson C, Nilsson M, Nilsson AG \& Lorentzon M. Low serum vitamin D is associated with higher cortical porosity in elderly men. Journal of Internal Medicine 2016280 496-508. (https://doi.org/10.1111/joim.12514)

43 Burghardt AJ, Issever AS, Schwartz AV, Davis KA, Masharani U, Majumdar S \& Link TM. High resolution peripheral quantitative computed tomographic imaging of cortical and trabecular bone microarchitecture in patients with type 2 diabetes mellitus. Journal of Clinical Endocrinology and Metabolism 201095 5045-5055. (https:// doi.org/10.1210/jc.2010-0226)

44 Shanbhogue VV, Hansen S, Frost M, Jørgensen NR, Hermann AP, Henriksen JE \& Brixen K. Compromised cortical bone compartment in type 2 diabetes mellitus patients with microvascular disease. European Journal of Endocrinology 2016174 115-124. (https://doi. org/10.1530/EJE-15-0860)
45 Vestergaard P, Rejnmark L \& Mosekilde L. Hypertension is a risk factor for fractures. Calcified Tissue International 200984 103-111. (https://doi.org/10.1007/s00223-008-9198-2)

46 Murad MH, Elamin KB, Abu Elnour NO, Elamin MB, Alkatib AA, Fatourechi MM, Almandoz JP, Mullan RJ, Lane MA, Liu H et al. CLINICAL REVIEW: The effect of vitamin D on falls: a systematic review and meta-analysis. Journal of Clinical Endocrinology and Metabolism 201196 2997-3006. (https://doi.org/10.1210/jc.2011-1193)

47 Lips P, Cashman KD, Lamberg-Allardt C, Bischoff-Ferrari HA, Obermayer-Pietsch BR, Bianchi Ml, Stepan J, Fuleihan GEH \& Bouillon R. Management of endocrine disease: current vitamin D status in European and Middle East countries and strategies to prevent vitamin D deficiency; a position statement of the European Calcified Tissue Society. European Journal of Endocrinology 2019180 23-54. (https://doi.org/10.1530/EJE-18-0736)

Received 14 March 2019

Revised version received 5 August 2019

Accepted 28 August 2019 